\title{
Rosette-forming glioneuronal tumour of the fourth ventricle: case report and review of the literature
}

\author{
Tayfun Hakan ${ }^{1}$, Fügen Vardar Aker ${ }^{2}$ \\ ${ }^{1}$ Memorial Ataşehir Hospital, Ataşehir/İstanbul, ${ }^{2}$ Haydarpaşa Numune Teaching and Research Hospital, Ataşehir/istanbul, Turkey
}

\begin{abstract}
Rosette-forming glioneuronal tumour (RGNT) of the fourth ventricle is one of the newly described primary tumours of the central nervous system. These tumours have two components of both neurocytic and glial areas but usually the glial component of the tumour predominates. They have biphasic cytoarchitecture with two elements; neurocytic rosettes resembling Homer-Wright rosettes, and astrocytic component resembling a pilocytic astrocytoma. They are low-grade tumours with lack of histopathological signs of malignancy. Here, clinical, magnetic resonance, computed tomography (CT) and pathological features of rosette-forming glioneuronal tumour of posterior fossa are presented. A 29-year-man was admitted with an acute neurological deterioration. A three ventricular hydrocephalus and a hypo-density around vermis in the posterior fossa were seen in his CT scans. He did well after an emergency external ventricular drainage. He had an elective operation and a mass that was reported to be a rosette-forming glioneuronal tumour of the fourth ventricle was excised.
\end{abstract}

Key words: cerebellum, fourth ventricle, glioneuronal tumour, neuropathology, rosette-forming glioneuronal tumour.

\section{Introduction}

Rosette-forming glioneuronal tumour (RGNT) of the fourth ventricle is one of the newly described primary tumours of the central nervous system [12]. Komori et al. [18] were the first who described this entity. They explained the characteristics of these tumours in terms of location, distinctive histological appearance with formation of neurocytic component and indolent biologic behaviour in a series of 11 cases report in 2002 [19]. Rosette-forming glioneuronal tumour was confirmed as a new type in the newly updated World Health Organization (WHO) classification of tumours of the central nervous system in 2007 [12]. Previously, these tumours assumed to be only infratentorial and located around fourth ventricle. Different locations of RGNT as chiasma [31], suprasellar region [30] and pineal region $[10,13,19,32]$, septum pellucidum [36], intraventricular dissemination [35] and two spinal cord [5,28] were published later.

Although the histopathological features of these tumours are regarded as distinct and typical, they can show wide spectral clinical symptoms (Table I). We aimed to make a case addition to the limited clinical, radiological and pathological experience of this kind of rare and "poorly" described tumours. 
Table I. Review of the literature of cases of rosette-forming glioneuronal tumour

\begin{tabular}{|c|c|c|c|c|c|c|}
\hline Author & No. & Sex, age & Presenting symptom & Location & Treatment & $\begin{array}{l}\text { Postoperative } \\
\text { morbidity }\end{array}$ \\
\hline \multirow[t]{11}{*}{ Komori et al. } & 1 & $25, M$ & Headache, $4^{\text {th }}$ nerve palsy & $\begin{array}{l}\text { 4. } V \text {, aquaduct, } \\
\text { pineal region }\end{array}$ & Biopsy & - \\
\hline & 2 & $59, M$ & Ataxia & 4. V, aquaduct & $\mathrm{ST}+\mathrm{RT}$ & + \\
\hline & 3 & $24, F$ & $\begin{array}{c}\text { Headache, ataxia, } \\
\text { dysartria }\end{array}$ & $\begin{array}{l}\text { 4. V, aquaduct, vermis, } \\
\text { pons }\end{array}$ & PR & - \\
\hline & 4 & $18, M$ & Seizure & 4. V, aquaduct & GTR & - \\
\hline & 5 & $40, \mathrm{~F}$ & Headache & 4. $\mathrm{V}$, vermis & GTR & + \\
\hline & 6 & $38, F$ & Headache & 4. V & GTR & - \\
\hline & 7 & $39, F$ & $\begin{array}{l}\text { Headache, neck pain, } \\
\text { blurred vision }\end{array}$ & 4. V, aquaduct & GTR & + \\
\hline & 8 & $27, M$ & $\begin{array}{l}\text { Headache, confusion, } \\
\text { ataxia }\end{array}$ & 4. V & PR & + \\
\hline & 9 & $18, F$ & $\begin{array}{l}\text { Incidental, headache, } \\
\text { ataxia }\end{array}$ & 4. V, aquaduct & $P R$ & + \\
\hline & 10 & $46, M$ & $\begin{array}{c}\text { Headache, blurred vision, } \\
\text { ataxia }\end{array}$ & 4. V, vermis, cerebellum & $P R$ & + \\
\hline & 11 & $12, \mathrm{~F}$ & Headache, ataxia & Tectum, aquaduct, pineal r. & PR & - \\
\hline Preusser et al.* & 12 & $35, M$ & Incidental & 4. V, vermis & Surgery! & Not known \\
\hline Adachi et al. & 13 & $18, \mathrm{~F}$ & Incidental, slight ataxia & 4. V & $P R$ & + \\
\hline Albanese et al. & 14 & $32, \mathrm{~F}$ & $\begin{array}{c}\text { Headache, cervical pain, } \\
\text { neck rigidity }\end{array}$ & 4. V & GTR & + \\
\hline \multirow[t]{3}{*}{ Jacques et al. } & 15 & $39, M$ & $\begin{array}{l}\text { Vertigo, headache, } \\
\text { diplopia, nystagmus }\end{array}$ & 4. V & GTR & - \\
\hline & 16 & $33, F$ & $\begin{array}{l}\text { Headache, diplopia, } \\
\text { ataxia, dysarthria, lethargy }\end{array}$ & 4. V & GTR & Not known \\
\hline & 17 & $42, M$ & Headache & 4. V & GTR & Not known \\
\hline Johnson et al. & 18 & $29, F$ & Headache, vertigo & 4. V & NGTR & Not known \\
\hline Rickert et al. & 19 & $16, \mathrm{~F}$ & $\begin{array}{c}\text { Therapy resistant back } \\
\text { pain }\end{array}$ & Spinal cord (C7-T2) & GTR & - \\
\hline \multirow[t]{2}{*}{ Vajtai et al. } & 20 & $16, \mathrm{~F}$ & $\begin{array}{c}\text { Vertigo, nausea, tinnitus, } \\
\text { ataxia }\end{array}$ & Roof of $4 . \mathrm{V}$ & GTR & + \\
\hline & 21 & $30, F$ & $\begin{array}{l}\text { Vertigo, vomiting, } \\
\text { headache, clumsy walking }\end{array}$ & Roof of $4 . \mathrm{V}$ & GTR & - \\
\hline \multirow[t]{2}{*}{ Pimentel et al. } & 22 & $38, F$ & Headache & 4. V & NGTR & + \\
\hline & 23 & $51, \mathrm{~F}$ & Dizziness & Cerebellum & GTR & - \\
\hline \multirow[t]{3}{*}{ Marhold et al. } & 24 & $20, M$ & $\begin{array}{c}\text { Somnolence, anisocoria, } \\
\text { ataxia }\end{array}$ & Pineal region, vermis, 4. V & GTR & + \\
\hline & 25 & $47, \mathrm{~F}$ & $\begin{array}{l}\text { Headache, ataxia, } \\
\text { hemiparesthesia }\end{array}$ & Inferior vermis & GTR & + \\
\hline & 26 & $39, F$ & $\begin{array}{l}\text { Headache, vertigo, } \\
\text { nausea, tinnitus }\end{array}$ & Foluculus, lateral (CPA) & GTR & - \\
\hline \multirow[t]{2}{*}{ Tan et al. } & 27 & $42, M$ & Headache, feeling "odd" & $\begin{array}{l}\text { Upper cerebellar } \\
\text { aquaduct }\end{array}$ & Biopsy & + \\
\hline & 28 & $38, F$ & Lightheadedness & Cerebellar vermis & Biopsy & - \\
\hline
\end{tabular}


Table I. Cont.

\begin{tabular}{|c|c|c|c|c|c|c|}
\hline Author & No. & Sex, age & Presenting symptom & Location & Treatment & $\begin{array}{l}\text { Postoperative } \\
\text { morbidity }\end{array}$ \\
\hline \multirow[t]{2}{*}{ Joseph et al. } & 29 & $38, F$ & Headache, vomiting & Cereballar vermis & GTR & - \\
\hline & 30 & $24, F$ & $\begin{array}{l}\text { Worsening of gait, } \\
\text { anisocoria }\end{array}$ & 4. V & $P R$ & - \\
\hline $\begin{array}{l}\text { Scheithauer } \\
\text { etal. }\end{array}$ & 31 & $23, M$ & $\begin{array}{l}\text { Eye pain, blurred vision, } \\
\text { headache }\end{array}$ & Chiasma & PR & - \\
\hline Anan et al. & 32 & $44, F$ & $\begin{array}{c}\text { Tetraparesis, dysesthesia, } \\
\text { neurogenic bladder }\end{array}$ & $\begin{array}{l}\text { Spinal cord, } \\
\text { cervicothoracic }\end{array}$ & GTR & $\begin{array}{c}+ \text { (slight aggra- } \\
\text { vation })\end{array}$ \\
\hline Wang et al. & 33 & $16, F$ & $\begin{array}{l}\text { Seizure, loss of } \\
\text { consciousness }\end{array}$ & ventricle & Biopsy & - \\
\hline Kinno et al. ${ }^{* *}$ & 34 & $18, M$ & Gait disturbance, ataxia & Cerebellar vermis & PR & - \\
\hline Li et al. & 35 & $27, M$ & $\begin{array}{l}\text { Headache, vomiting, } \\
\text { clumsy walking }\end{array}$ & 4. $V$ & GTR & - \\
\hline Arai et al. & 36 & $15, F$ & Headache & 4. V, ventricle, vermis & GTR & + \\
\hline Luan et al. & 37 & $30, F$ & Headache & $\begin{array}{l}\text { Right cerebellar } \\
\text { hemisphere }\end{array}$ & GTR & - \\
\hline Ghosal et al. & 38 & $22, M$ & $\begin{array}{l}\text { Headache, diplopia } \\
\text { (3 } 3^{r d} \text { nerve palsy) }\end{array}$ & Pineal gland \& tectum & $\begin{array}{l}\text { Decompres- } \\
\text { sion? }\end{array}$ & - \\
\hline $\begin{array}{l}\text { Frydenberg } \\
\text { et al. }\end{array}$ & 39 & $29, M$ & $\begin{array}{l}\text { Headache, vomiting, } \\
\text { decrease in the level } \\
\text { of consciousness }\end{array}$ & Pineal gland & GTR & - \\
\hline Matyja et al. & 40 & $20, F$ & $\begin{array}{l}\text { Headache, nausea, } \\
\text { balance disturbance }\end{array}$ & 4. V & PR & $?$ \\
\hline \multirow[t]{2}{*}{ Sharma et al. } & 41 & $16, F$ & Headache, diplopia & Midbrain & Biopsy + RT & - \\
\hline & 42 & $17, M$ & Loss of consciousness & Suprasellar, 3rd ventricle & Biopsy & - \\
\hline Gessi et al. & 43 & $18, M$ & Not known & Vermis & GTR & - \\
\hline Fushimi et al. & 44 & $28, F$ & Intermittent headache & Cerebellar midline & PR & - \\
\hline \multirow[t]{8}{*}{ Ellezam et al. } & 45 & $29, F$ & Not known & Inf vermis/4. V & Not known & Not known \\
\hline & 46 & $23, F$ & Not known & Inf vermis/4. V & Not known & Not known \\
\hline & 47 & $12, M$ & Not known & Inf vermis/4. V & Not known & Not known \\
\hline & 48 & $50, M$ & Not known & Inf vermis/4. V & Not known & Not known \\
\hline & 49 & $45, M$ & Not known & Midbrain/tectal & Not known & Not known \\
\hline & 50 & $18, F$ & Not known & Inf vermis/4. V & Not known & Not known \\
\hline & 51 & $30, F$ & Not known & $3^{\text {rd }} \mathrm{V}$ & Not known & Not known \\
\hline & 52 & $15, M$ & Not known & Inf vermis/4th $\mathrm{V}$ & Not known & Not known \\
\hline Karafin et al. & 53 & $18, ?$ & Developmental delay & Posterior fossa & GTR & - \\
\hline Solis et al. & 55 & $16, F$ & Headache, vomiting & Pineal region & $P R$ & - \\
\hline Xiong et al. & 56 & $38, M$ & Visual disturbance & Septum pellicidum & $P R$ & - \\
\hline Podlesek et al. & 57 & $70, M$ & Persistant vertigo & Vermis, 4. V & GTR & - \\
\hline Present study & 58 & $29, M$ & $\begin{array}{c}\text { Neurological deterioration } \\
\text { with somnolence }\end{array}$ & Vermis, 4. V & NGTR & - \\
\hline
\end{tabular}

$P R$ - partial removal, GTR - gross total removal, RT - radiotherapy, NGTR - nearly gross total removal

*This case reported again in Marhold serious

${ }^{* *}$ One of the cases presented in this report had been published previously by Adachi et al. 


\section{Case report}

A 29-year-man was admitted with an acute neurological deterioration and somnolence. His neurological examination was normal except a positive Babinski sign on his right side. In his medical history, there was a diagnosis of an incidental and asymptomatic hydrocephalus that was seen in his cranial computed tomography (CT) following a mild head injury three years before. A cranial CT showed a three ventricular hydrocephalus and a hypodensity around
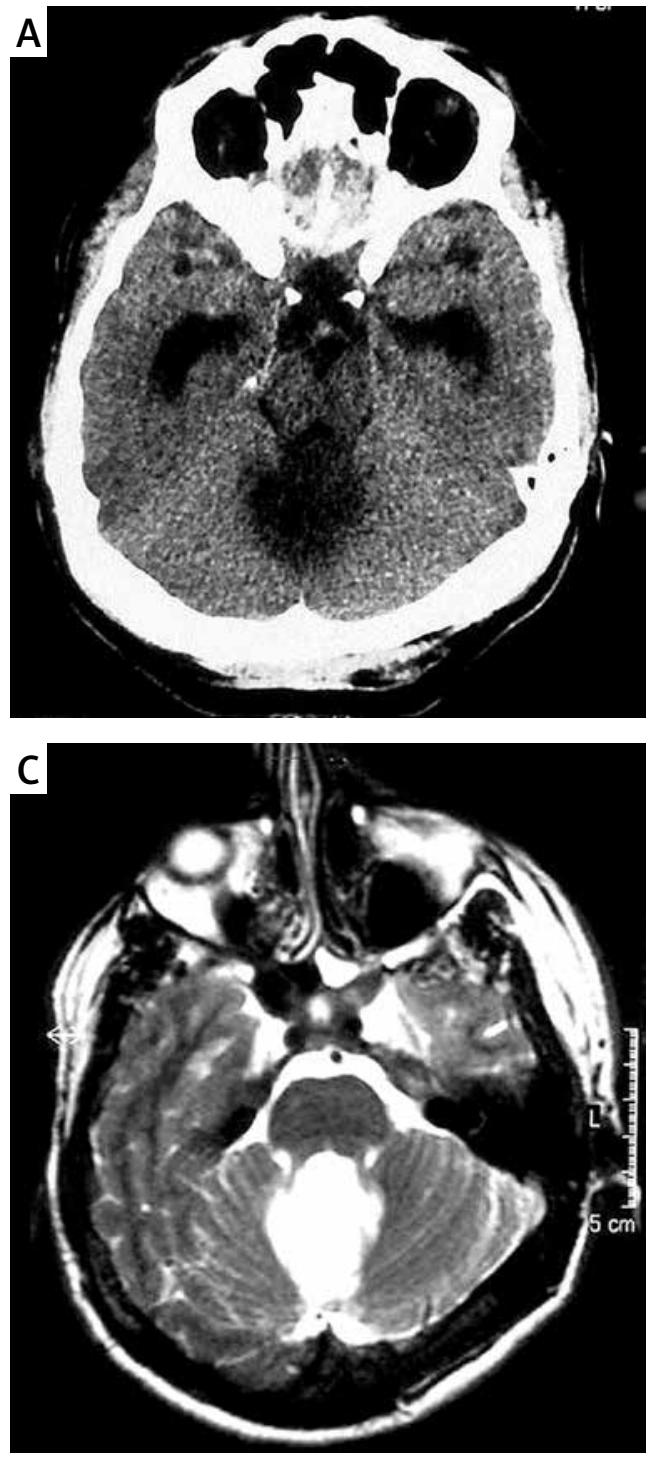

vermis in the posterior fossa (Fig. 1A). A cranial magnetic resonance imaging (MRI) revealed a partly cystic lesion located in vermis. It was hypointense on T1 and hyperintense on T2 weighted images and had no contrast enhancement (Fig. 1B-D). The lesion was hyperintense on flair sequences. The neurological status of the patient improved promptly following an emergent external ventricular drainage insertion. On the following day, the patient underwent an operation and a nearly gross total tumour removal was performed.
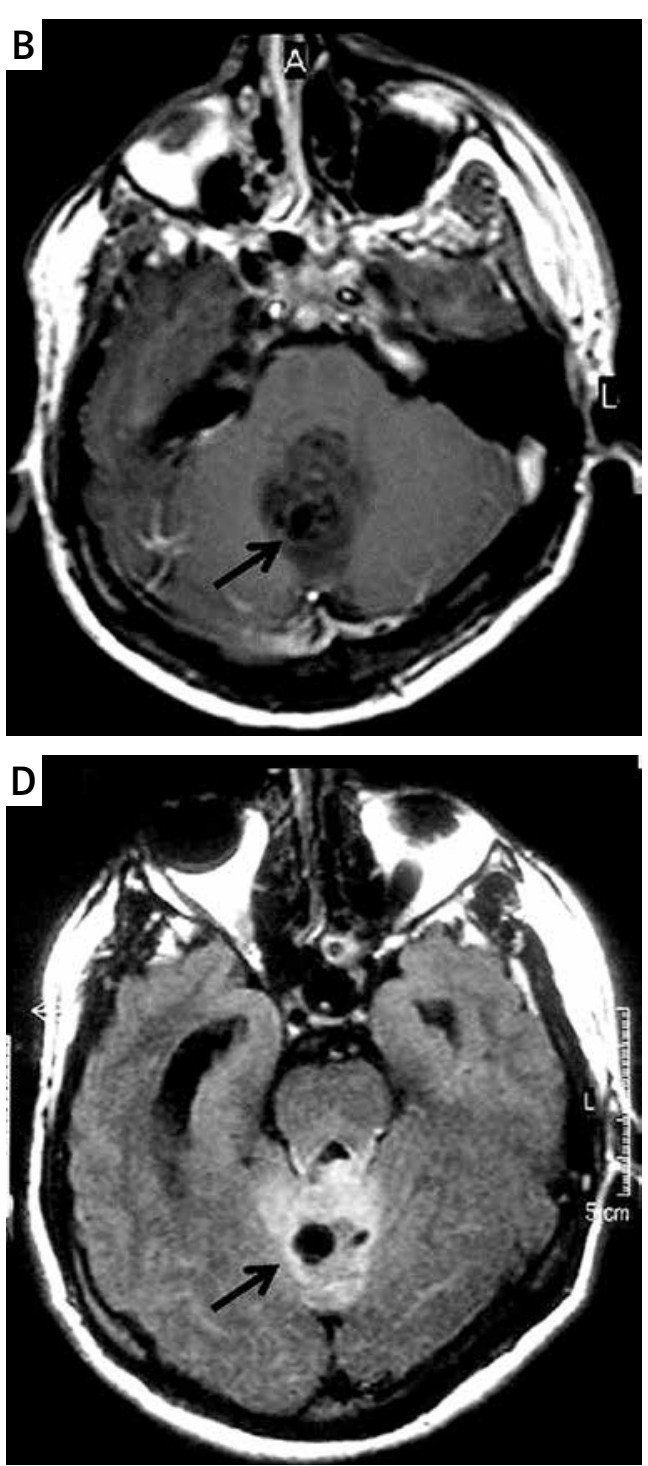

Fig. 1. A) Non-contrast computed tomography scan shows a hypodense lesion at vermis. B) On T1 weighted magnetic resonance scans this lesion shows heterogeneous contrast enhancement and a cystic component also is found (arrow) in the lesion. C) The lesion seems hyperintense on T2 weighted magnetic resonance imaging (MRI). D) On flair weighted MRI images the lesion seems hyperintense but the cystic component is hypointense (arrow). 
The resected tumour specimen was transferred to the pathology department after fixing in a phosphate buffered $4 \%$ solution of formalin. Serial sections of $5 \mu \mathrm{m}$ thick paraffin-embedded tumour tissues were stained with hematoxylin and eosin (HE). Additionally, an immunohistochemical (IHC) staining with monoclonal antibodies against glial fibrillary acidic protein (GFAP) (1:75; Neomarkers, Fremont, CA, USA), synaptophysin (1:100; Neomarkers) and Ki 67 (1 : 50; Neomarkers) was performed. Immunohistochemical staining was performed using an enhancement method based on a repetitive microwave heating technique using sodium citrate buffer. In microscopic examination, the tumour consisted of two components and it was also well demarcated from cerebellar tissue. The tumour was charac- terized by glial and neuronal components (Fig. 2A). In the area of the glial component, the cytoplasmic processes formed a compact textured fibrillary background. Some areas resembled pilocytic astrocytoma and oligodendroglioma (Fig. 2D). There were a few Rosenthal fibres and hemosiderin deposits. The neurocytic component consisted of uniform neurocytes which are forming rosettes and pseudorosettes (Fig. 2B-C). Neurocytic tumour cells had ovoid or round nuclei with fine chromatin pattern, inconspicuous nucleoli and delicate cytoplasmic processes. Overall, cellularity was low. Mitosis, atypia, necrosis or vascular proliferations were not seen. In immunohistochemical examination, synaptophysin immunoreactivity was only restricted in the peripapillary area of perivascular pseudorosette and rosette
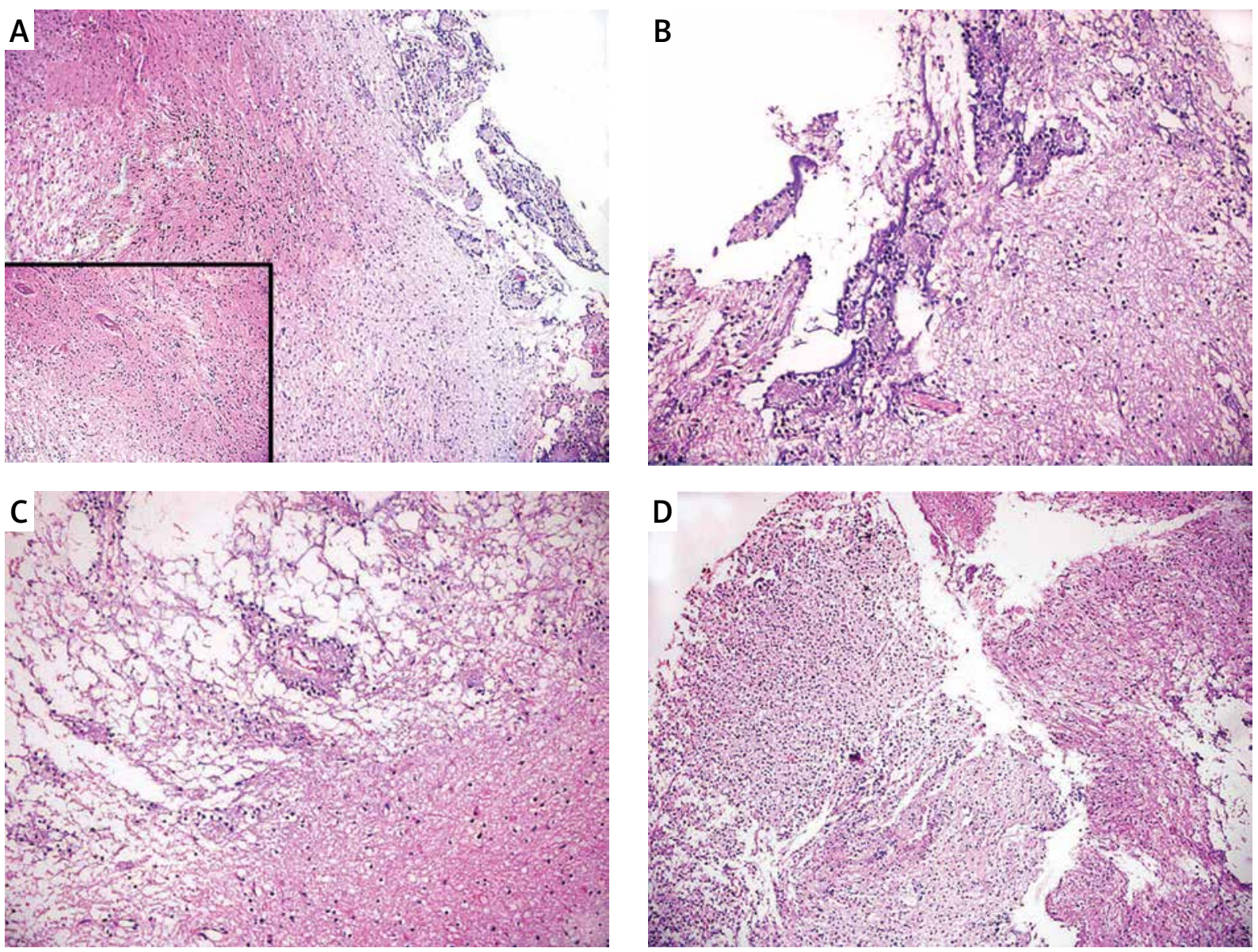

Fig. 2. Two components: neurocytic and astrocytic ( $\mathrm{H} \& \mathrm{E} \times 40)$, pilocytic astrocytoma like component on the left side (H\&E x200). A) Neurocytic pseudorosettes and rosettes around the astrocytic component. B) Neurocytic pseudorosette: delicate cell processes radiating toward a capillary $(H \& E \times 100)$. C) The other glial area resembling oligodendroglioma intermingle with pilocytic astrocytoma like area $(H \& E \times 100)$. D) There is no mitosis and atypical histopathological findings. 
(Fig. 3A). Staining with GFAP antibody was positive in the astrocytic component of the tumour (Fig. 3B). Ki 67 labelling index was very low (1\% and below). The tumour was reported to be a rosette-forming glioneuronal tumour of the fourth ventricle.

The postoperative period was unremarkable. He was followed for 32 months without evidence of progressive clinical deterioration.

\section{Discussion}

Kuchelmeister et al. [20] reported a dysembryoplastic neuroepithelial tumour (DNT) in cerebellum which morphologically resembled RGNT in 1995. The term rosette-forming glioneuronal tumour was used to define the low-grade tumour of the fourth ventricle by Komori et al. [18] for the first time in 1998. The characteristic features of these tumours were explained as 1) its unique location, 2) neurocytic pseudo-rosette formation and 3) the presence of a pilocytic astrocytoma component. Until the publishing of two cases that were located in chiasma [31] and spinal cord [5], these tumours were believed to be found only in posterior fossa. So, the "unique location" of these tumours seems to need some change. Anan et al. [5] suggested that the lesion might derive from the gray matter or the middle motor nuclei in the spinal cord, so RGNT may not be limited in distribution [5]. Scheithauer et al. [31] reported that periventricular germinal matrix is the likely origin of RGNTs and so, they may be occurring in "ectopic" sites. Rosette-forming glioneuronal tumours may be located in different areas such as the pineal region $[9,10]$ and lateral ventricles [35] and some satellite tumours may also be seen in the patients [6,18,27,33].

Rosette-forming glioneuronal tumour is encountered more frequently in females. Thirty-one of the 56 reported cases in the English literature, including the present case, up to date were seen in women. Patient age was $12-70$ years with a mean of 29 years (Table I).

Headache and cerebellar signs as ataxia and nystagmus are the most common initial clinical symptoms. Diplopia, ptosis [13], dysarthria [13,19], blurred vision [19], seizure [19,35], dizziness [25], vertigo [14,34], vomiting [21,34), clumsy walking $[21,23]$ and neck pain and rigidity $[2,19]$ are the other signs and symptoms of this tumour. Lethargy [13], somnolence, loss of conscious [35] and anisocoria [23] due to increased intracranial pressure may also be seen in these patients as in the presented case. However, there are some cases which are diagnosed incidentally $[1,19,27]$, too.

A three ventricular hydrocephalus may be seen in RGNT patients. It can be so serious that a ventriculo-peritoneal shunt [13] or insertion of an external ventricular drainage (EVD) may be required [10,23]. We also performed an EVD in the emergency room for the presented case, because the patient was admitted with an acute neurological deterioration with somnolence. Fortunately, most of these tumours are slowly growing lesions. The development of ventriculomegaly can be chronic and may be clinically compensated [23].

The radiological findings of RGNTs may show some variations. These lesions are relatively circumscribed and heterogeneous, they may have some cal-
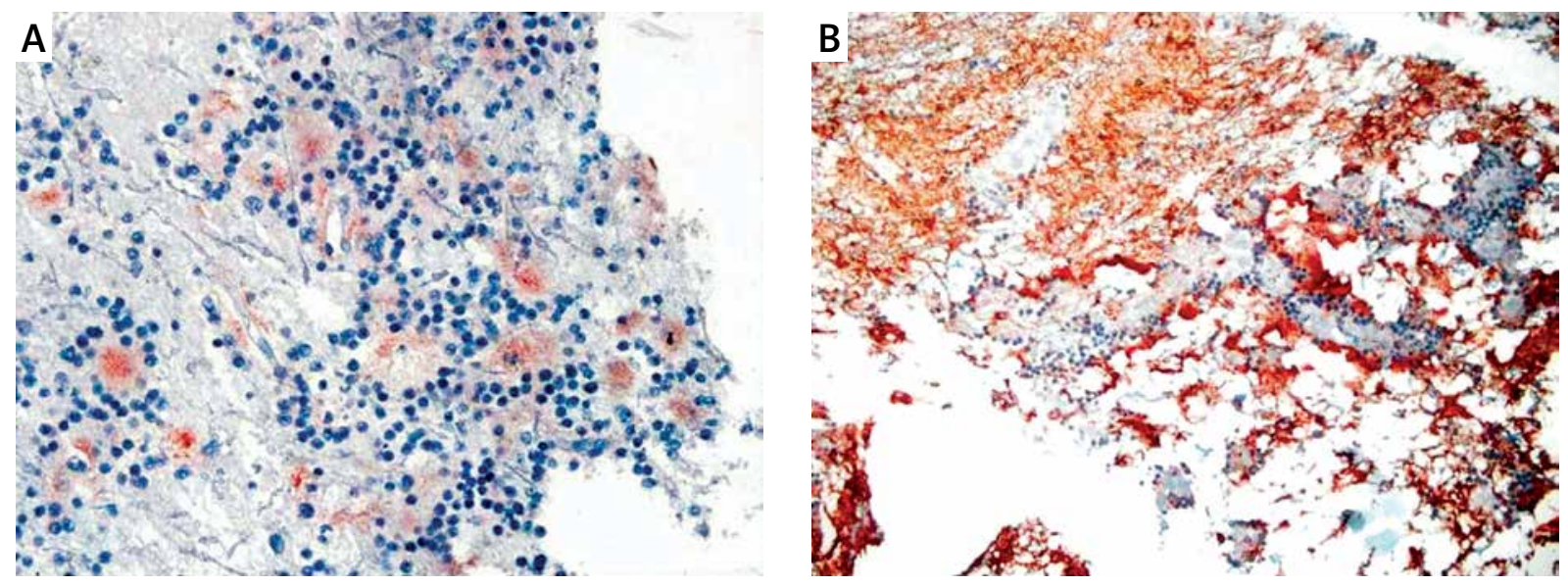

Fig. 3. In immunohistochemical study synaptophysin is present at the centre of neurocytic rosettes (A) and glial fibrillary acidic protein (GFAP) immunoreactivity is present in the glial component (B). 
cifications and cystic components [4,11,13,21,23,27]. Some smaller tumour nodules may accompany these tumours $[19,23,27]$. These tumours are usually hypointense on $\mathrm{T} 1$ and hyperintense or isointens on T2 weighted MRI sequences [10]. They may have no contrast enhancement as in our case or may have a ring shaped contrast enhancement that led to consideration of malignancy $[24,27]$. Low density on non-enhanced CT as in the presented case is also typical of these lesions [4]. These tumours may show evidence of previous intratumoral haemorrhage on MRI $[21,30]$.

Rosette-forming glioneuronal tumours have two components of both neurocytic and glial areas, but usually the glial component of the tumour predominates [3]. Rosette-forming glioneuronal tumours are low-grade tumours with no histopathological signs of malignancy $[1,27]$. They have a low labelling index of Ki-67 antigen, minimal or no cellular atypia and there is no evidence of recurrence, increase in tumour size or metastasis until now [19]. Solis et al. [32] found mutations of isocitrate dehydrogenase 1 (IDH1) and IDH2 that are relatively specific of diffuse gliomas; but Xiong et al. [36] did not detect somatic mutations of IDH1 and IDH2 in their cases. PIK3CA mutations were other mutations reported in RGNT [7]. PIK3CA mutants are seen with high frequencies in glioblastomas and anaplastic oligodendrogliomas.

The recommended treatment modality of these tumours is surgery. As these tumours are accepted low-grade in nature, an aggressive approach can increase surgical morbidity [15]; so, subtotal removal or gross total removal may be chosen. Until now, 4 cases of recurrence have been reported. The recurrence time of the tumours was 10 years in 2 cases $[13,19]$ and 9 and 4 years in the others [7].

The main differential diagnosis of RGNT includes pilocytic astrocytoma (PA), dysembryoplastic neuroepithelial tumour, central neurocytoma, plexus papilloma, oligodendroglioma, ependymoma, primitive neuroectodermal tumour (PNET), glioneuronal tumour with neuropil-like islands (rosette) glioneuronal tumour, papillary glioneuronal tumour and metastasis $[3,15,19,29]$. Pilocytic astrocytoma is the most difficult tumour type for differential diagnosis with RGNT. Pilocytic astrocytoma has small round cells as well as astrocytic cells but rosette structures like those of RGNT are not found in PA [17,19]. There is also no evidence of neural differentiation in the rounded cells of pilocytic astrocytoma [3]. Dysem- bryoplastic neuroepithelial tumour has mature neurons in mucinous pools that help for differentiating from RGNT. Rosette-forming glioneuronal tumour does not have "floating neurons" as is the case for the "specific glioneuronal element" of DNT [34]. Central neurocytoma is characterized by uniform round cells and has similar immunohistochemical features of neuronal differentiation as in RGNT, but it does not have biphasic architecture with a distinctly separate glial component and true neurocytic rosette formation [35]. Central neurocytomas have no astrocytic components as RGNTs. Although neurocytes or well-formed rosettes may be found in oligodendrogliomas, oligodendroglial components are not seen in RGNTs [6]. The distribution pattern of synaptophysin and GFAP staining in ependymomas are quite the opposite to that seen in RGNTs [34].

In conclusion, RGNTs are clinically slow-growing tumours and typically occur in the midline. They affect mainly young adults with a slight female predominance. They can be seen outside the posterior fossa as ectopic tumours. They have biphasic cytoarchitecture with two elements; neurocytic rosettes resembling Homer-Wright rosettes and astrocytic component resembling a pilocytic astrocytoma. Glioneuronal tumours are a heterogeneous entity; so, further pathologic and clinical subclassifications may be required for prognostication and treatment. Careful and long-term follow-up monitoring will be wise for these uncommon tumours.

\section{Disclosure}

Authors report no conflict of interest.

\section{References}

1. Adachi J, Nishikawa R, Hirose T, Matsutani M. Mixed neuronal-glial tumor of the fourth ventricle and successful treatment of postoperative mutism with bromocriptine: case report. Surg Neurol 2005; 63: 375-379.

2. Albanese A, Mangiola A, Pompucci A, Sabatino G, Gessi M, Lauriola L, Anile C. Rosette-forming glioneuronal tumour of the fourth ventricle: report of a case with clinical and surgical implications. J Neurooncol 2005; 71: 195-197.

3. Allende DS, Prayson RA. The expanding family of glioneuronal tumors. Adv Anat Pathol 2009; 16: 33-39.

4. Amemiya S, Shibahara J, Aoki S, Takao H, Ohtomo K. Recently established entities of central nervous system tumors: review of radiological findings. J Comput Assist Tomogr 2008; 32: 279-285.

5. Anan M, Inoue R, Ishii K, Abe T, Fujiki M, Kobayashi H, Goya T, Nakazato $Y$. A rosette-forming glioneuronal tumor of the spinal 
cord: the first case of a rosette-forming glioneuronal tumor originating from the spinal cord. Hum Pathol 2009; 40: 898-901.

6. Arai A, Sasayama T, Tamaki M, Sakagami Y, Enoki E, Ohbayashi C, Kohmura E. Rosette-forming glioneuronal tumor of the fourth ventricle - case report. Neurol Med Chir (Tokyo) 2010; 50: 224-228.

7. Ellezam B, Theeler BJ, Luthra R, Adesina AM, Aldape KD, Gilbert MR. Recurrent PIK3CA mutations in rosette-forming glioneuronal tumor. Acta Neuropathol 2012; 123: 285-287.

8. Gessi M, Waha A, Setty P, Waha A, Pietsch T. Analysis of KIAA1549-BRAF fusion status in a case of rosette-forming glioneuronal tumor of the fourth ventricle (RGNT). Neuropathology 2011; 31: 654-657.

9. Ghosal N, Furtado SV, Hegde AS. Rosette forming glioneuronal tumor pineal gland and tectum: An intraoperative diagnosis on smear preparation. Diagn Cytopathol 2010; 38(8):590-593.

10. Frydenberg E, Laherty R, Rodriguez M, Ow-Yang M, Steel T. A rosette-forming glioneuronal tumour of the pineal gland. J Clin Neurosci 2010; 17:1326-1328.

11. Fushimi Y, Miyasaki A, Taki H, Aoyama K, Hirato J, Kanagaki M, Togashi K. Rosette-forming glioneuronal tumor of the fourth ventricle with bilateral olivary degeneration. Jpn J Radiol 2011; 29: 445-448.

12. Hainfellner JA, Scheithauer BW, Giangaspero F, Rosenblum MK. Rosette-forming glioneuronal tumor of the 4th ventricle (RGNT). In: World Health Organization Classification of Tumours of the Central Nervous System. Louis DN, Ohgaki H, Wiestler OD, Cavenee W (eds.). IARC, Lyon 2007; 115-116.

13. Jacques TS, Eldridge C, Patel A, Saleem NM, Powell M, Kitchen ND, Thom M, Revesz T. Mixed glioneuronal tumour of the fourth ventricle with prominent rosette formation. Neuropathol Appl Neurobiol 2006; 32: 217-220.

14. Johnson M, Pace J, Burroughs JF. Fourth ventricle rosette-forming glioneuronal tumor. Case report. J Neurosurg 2006; 105: 129-131.

15. Joseph V, Wells A, Kuo YH, Halcrow S, Brophy B, Scott G, Manavis J, Swift J, Blumbergs PC. The 'rosette-forming glioneuronal tumor' of the fourth ventricle. Neuropathology 2009; 29: 309-314.

16. Karafin M, Jallo GI, Ayars M, Eberhart CG, Rodriguez FJ. Rosette forming glioneuronal tumor in association with Noonan syndrome: pathobiological implications. Clin Neuropathol 2011; 30: 297-300

17. Kinno M, Ishizawa K, Shimada S, Masaoka H, Doi M, Seyama S, Komori T, Hirose T. Cytology is a useful tool for the diagnosis of rosette-forming glioneuronal tumour of the fourth ventricle: a report of two cases. Cytopathology 2010; 21: 194-197.

18. Komori T, Scheithauer BW, Sung JH. Rosette-forming mixed neuronal-glial tumour in the fourth ventricle. Neuropathol Exp Neurol 1998; 57: 520 [Abstract].

19. Komori T, Scheithauer BW, Hirose T. A rosette-forming glioneuronal tumor of the fourth ventricle: infratentorial form of dysembryoplastic neuroepithelial tumor? Am I Surg Pathol 2002; 26: 582-591.

20. Kuchelmeister K, Demirel T, Schlörer E, Bergmann M, Gullotta F. Dysembryoplastic neuroepithelial tumour of the cerebellum. Acta Neuropathol 1995; 89: 385-390.

21. Li YM, Li WO, Pan Y, Lu YC, Long NY, Tao XF, Yu HY. Rosette-forming glioneuronal tumour of the fourth ventricle with previous intratumoural haemorrhage: case report and review of the literature. J Int Med Res 2009; 37: 958-966.

22. Luan S, Zhuang D, Sun L, Huang FP. Rosette-forming glioneuronal tumor (RGNT) of the fourth ventricle: Case report and review of literature. Clin Neurol Neurosurg 2010; 112: 362-364.

23. Marhold F, Preusser M, Dietrich W, Prayer D, Czech T. Clinicoradiological features of rosette-forming glioneuronal tumor (RGNT) of the fourth ventricle: report of four cases and literature review. J Neurooncol 2008; 90: 301-308.

24. Matyja E, Grajkowska W, Nauman P, Ozieblo A, Bonicki W. Rosette-forming glioneuronal tumor of the fourth ventricle with advanced microvascular proliferation - a case report. Neuropathology 2011; 31: 427-432.

25. Pimentel J, Resende M, Vaz A, Reis AM, Campos A, Carvalho H, Honavar M. Rosette-forming glioneuronal tumor: pathology case report. Neurosurgery 2008; 62: E1162-1163.

26. Podlesek D, Geiger K, Hendry DJ, Schackert G, Krex D. Rosette-forming glioneuronal tumor of the fourth ventricle in an elderly patient. J Neurooncol 2011; 103: 727-731.

27. Preusser M, Dietrich W, Czech T, Prayer D, Budka H, Hainfellner JA. Rosette-forming glioneuronal tumor of the fourth ventricle. Acta Neuropathol 2003; 106: 506-508.

28. Rickert CH, Jasper M, Sepehrnia A, Jeibmann A. Rosetted glioneuronal tumour of the spine: clinical, histological and cytogenetic data. Acta Neuropathol 2006; 112: 231-233.

29. Rosenblum MK. The 2007 WHO Classification of Nervous System Tumors: newly recognized members of the mixed glioneuronal group. Brain Pathol 2007; 17: 308-313.

30. Sharma P, Swain M, Padua MD, Ranjan A, Lath R. Rosette-forming glioneuronal tumors: a report of two cases. Neurol India 2011; 59: 276-280.

31. Scheithauer BW, Silva Al, Ketterling RP, Pula JH, Lininger JF, Krinock MJ. Rosette-forming glioneuronal tumor: report of a chiasmal-optic nerve example in neurofibromatosis type 1: special pathology report. Neurosurgery 2009; 64: E771-772.

32. Solis OE, Mehta RI, Lai A, Mehta RI, Farchoukh LO, Green RM, Cheng JC, Natarajan S, Vinters HV, Cloughesy T, Yong WH. Rosette-forming glioneuronal tumor: a pineal region case with IDH1 and IDH2 mutation analyses and literature review of 43 cases. J Neurooncol 2011; 102: 477-484.

33. Tan CC, Gonzales M, Veitch A. Clinical implications of the infratentorial rosette-forming glioneuronal tumor: case report. Neurosurgery 2008; 63: E175-176.

34. Vajtai I, Arnold M, Kappeler A, Jeless O, Lukes A, Mariani L, Paulus W. Rosette-forming glioneuronal tumor of the fourth ventricle: report of two cases with a differential diagnostic overview. Pathol Res Pract 2007; 203: 613-619.

35. Wang Y, Xiong J, Chu SG, Liu Y, Cheng HX, Wang YF, Zhao Y, Mao $Y$. Rosette-forming glioneuronal tumor: report of an unusual case with intraventricular dissemination. Acta Neuropathol 2009; 118: 813-819.

36. Xiong J, Liu Y, Chu SG, Chen H, Chen HX, Mao Y, Wang Y. Rosette-forming glioneuronal tumor of the septum pellucidum with extension to the supratentorial ventricles: rare case with genetic analysis. Neuropathology 2012; 32: 301-305. 